\title{
Alternative splicing of follicle-stimulating hormone receptor pre-mRNA: cloning and characterization of two alternatively spliced mRNA transcripts
}

\author{
R Kraaij, M Verhoef-Post, J A Grootegoed and A P N Themmen \\ Department of Endocrinology and Reproduction, Faculty of Medicine and Health Sciences, Erasmus University Rotterdam, PO Box 1738, 3000 DR Rotterdam, \\ The Netherlands \\ (Requests for offprints should be addressed to A P N Themmen)
}

\begin{abstract}
Glycoprotein hormone receptors contain a large extracellular domain that is encoded by multiple exons, facilitating the possibility of expressing alternatively spliced transcripts. We have cloned two new splice variants of the rat follicle-stimulating hormone (FSH) receptor gene: FSH-R1 and FSH-R2. The splice variant FSH-R1 differs from the full-length FSH receptor mRNA by the inclusion of a small extra exon between exons 9 and 10 . FSH-R2 lacks the first three base pairs of exon 4, contains an extra exon between exons 4 and 5, and has an extended 3 -untranslated region. According to the predicted open reading frames, both mRNAs encode truncated FSH receptor proteins, consisting of the entire extracellular domain (FSH-R1) or the amino-terminal half of the extracellular domain (FSH-R2), and are expressed at a low
\end{abstract}

level in testes and ovaries. The levels of expression of the FSH-R1 and FSH-R2 mRNAs in the gonads show a constant ratio to the expression level of the full-length FSH receptor mRNA. Furthermore, in vitro co-expression of either one of the truncated proteins with the full-length FSH receptor in COS1 cells did not affect signal transduction through the full-length FSH receptor. The absence of a function of the truncated FSH receptors in FSH signal transduction in vitro, and the lack of differential regulation of the alternative transcripts, indicate that there is no clear function for alternative splicing of the FSH receptor pre-mRNA in the postnatal testis and the cycling adult ovary.

Journal of Endocrinology (1998) 158, 127-136

\section{Introduction}

The gonadotropins luteinizing hormone (LH) and folliclestimulating hormone (FSH) have key roles in the regulation of ovarian and testicular functions (extensively reviewed in Carr 1992, Griffin \& Wilson 1992). The LH receptor (Loosfelt et al. 1989, McFarland et al. 1989) and the FSH receptor (Sprengel et al. 1990) belong to the large family of GTP-binding protein ( $G$ protein)-coupled receptors and are located at the plasma membrane of the target cells. Together with the thyroid-stimulating hormone (TSH) receptor (Parmentier et al. 1989), these receptors form a subgroup of glycoprotein hormone receptors because they have a large glycosylated extracellular domain of approximately the same size as the transmembrane domain, which is in contrast to almost all other $G$ protein-coupled receptors. This extracellular domain is involved in hormone binding (Braun et al. 1991) and is encoded by multiple exons (Gross et al. 1991, Heckert et al. 1992, Tsai-Morris et al. 1990). The first ten exons of the LH receptor gene encode the extracellular domain, whereas the last exon encodes both the transmembrane and the intracellular domains (Tsai-Morris et al. 1990). In the FSH and TSH receptor genes, each consisting of ten exons (Gross et al. 1991, Heckert et al. 1992), the extracellular domain is encoded by the first nine exons.

Shortly after the gonadotropin receptor cDNAs were cloned, it became apparent that alternatively spliced transcripts are co-expressed with the full-length receptor mRNA transcript (reviewed in Themmen et al. 1994, Misrahi et al. 1996, O’Shaughnessy et al. 1996). Alternative transcripts encode truncated receptors with two distinct structures: either receptor proteins containing the signal peptide and a part of the extracellular domain but no transmembrane domain, or receptor proteins that lack a part of the extracellular or intracellular domain but still contain the transmembrane domain. Of the latter form, a C-terminally truncated ovine-FSH receptor has been described (Sairam et al. 1996). The protein has a membrane location, binds FSH, but is unable to transduce signal. In vitro co-expression of this protein together with the full-length FSH receptor results in attenuation of full-length receptor signal transduction (Sairam et al. 1996). 
Truncated receptor proteins that lack the transmembrane domain may be secreted, although this remains equivocal. Transient expression of truncated $\mathrm{LH}$ receptors in HEK293 cells did not result in secretion (Xie et al. 1990), whereas a similar protein showed partial secretion from transiently transfected COS7 cells (VuHai-LuuThi et al. 1992). The latter authors also showed that the secreted protein, when co-expressed with the full-length receptor molecule, enhanced human chorionic gonadotropin (hCG)-induced cAMP production (VuHai-LuuThi et al. 1992). Another function of alternative splicing of the gonadotropin receptors may be the regulation of receptor gene expression at the post-transcriptional level. In prenatal female rats, splice variants of the $\mathrm{LH}$ receptor gene are expressed, whereas the full-length receptor transcript could not be detected (Sokka et al. 1992). Expression of this transcript could only be detected from day 7 of neonatal life onward. In this situation, expression of a functional LH receptor during the perinatal period is prevented, despite continuous transcription of the $\mathrm{LH}$ receptor gene (Sokka et al. 1992). For the LH receptor in the testis and the FSH receptor in the testis and the ovary, a delay of only 2 days was observed before the appearance of the full-length receptor transcript (Rannikki et al. 1995, Zhang et al. 1994). Functional studies on splice variants of the related TSH receptor have mainly addressed possible involvement of secreted receptor proteins in the development of Graves' disease (Ligett et al. 1991, Graves et al. 1992, 1995). To date, no clear evidence exists that shows the involvement of circulating truncated TSH receptors in this autoimmune disease.

In the present paper, we report the cloning of two splice variants of the rat FSH receptor gene. In view of the possible biological importance of truncated glycoprotein hormone receptors, we have studied the expression and putative function of these FSH receptor variants.

\section{Materials and Methods}

\section{Cloning of FSH-R1 and FSH-R2}

A rat Sertoli cell directional cDNA library (Baarends et al. 1994) in lambda ZAP II (Stratagene, Westburg, Leusden, The Netherlands) consisting of $1.5 \times 10^{6}$ independent clones was screened with two rat $\mathrm{FSH}$ receptor cDNA probes, corresponding to the $5^{\prime}$-part (positions -71 to 791) and the $3^{\prime}$-part (positions 793 to 2095) of the FSH receptor cDNA (Sprengel et al. 1990). $\alpha-\left[{ }^{32} \mathrm{P}\right] \mathrm{dATP}$ (Amersham, 's Hertogenbosch, The Netherlands)-labeled probes (Feinberg \& Vogelstein 1983) were used to screen approximately $10^{6}$ plaques (Sambrook et al. 1989). Two positive plaques were purified during two subsequent rescreen rounds. pBluescript SK plasmids containing the positive clones were isolated according to the in vivo excision protocol described by the manufacturer.
The positive clones were subjected to restriction enzyme analysis and compared with the published FSH receptor cDNA (Sprengel et al. 1990). Nucleotides and amino acids are numbered according to this published rat FSH receptor cDNA. Sequence analysis was performed of both clones in one orientation according to the dideoxy chain termination method (Sanger et al. 1977), using primers derived from cDNA sequences. Sequences that differed from the published cDNA were sequenced in both orientations. Both clones were found to be splice variants of the FSH receptor gene. No attempts were made to screen the library again in order to obtain a full-length (wild type) FSH receptor cDNA, as this cDNA could easily be constructed by exchanging the 384 base pairs NcoI/Bsu36I fragment (positions 704 to 1088) of FSH-R2 into FSH-R1 (see Fig. 1). Expression vectors were constructed by cloning the EcoRI/BamHI fragments of full-length FSH receptor, FSH-R1 and FSH-R2 (positions -71 to 2095) into the EcoRI/BamHI sites of pSG5 (Green et al. 1988).

\section{$R N A$ preparation and $R$ Nase protection assay}

Wistar rats, locally bred, were maintained under controlled conditions $\left(20-23^{\circ} \mathrm{C}\right.$, lights on from 0500 to $\left.1900 \mathrm{~h}\right)$. Animal care was in accordance with the Guidelines on the Handling and Training of Laboratory Animals (Universities Federation of Animal Welfare).

Total testes were isolated from 21-day-post-coitus (p.c.) fetuses, 21-day-old immature rats and 56-day-old mature rats, and snap frozen in liquid nitrogen. Folliculogenesis and ovulation were induced in 30-day-old immature rats by injecting (s.c.) $30 \mathrm{IU}$ pregnant mare serum gonadotropin (PMSG; Folligonan, Intervet, Boxmeer, The Netherlands) followed, $56 \mathrm{~h}$ later, by injecting (s.c.) $10 \mathrm{IU}$ hCG (Pregnyl; Organon International NV, Oss, The Netherlands). Ovaries were isolated and snap frozen in liquid nitrogen $0,24,48,72$ and $168 \mathrm{~h}$ after the PMSG injection. Sertoli cells were isolated from 21-day-old rats (Themmen et al. 1991), cultured for 4 days in the absence of FSH, and then stimulated for $4 \mathrm{~h}$ with $500 \mathrm{ng} / \mathrm{ml}$ ovine FSH-S16 (NIH, Bethesda, MD, USA) in order to downregulate FSH receptor mRNA levels, as described previously (Themmen et al. 1991). Total RNA was isolated from tissues and isolated cells using the $\mathrm{LiCl} /$ urea method (Auffray \& Rougeon 1980).

RNase protection assays were performed using FSH-R1 and FSH-R2 specific probes. For FSH-R1, a 485-base pair Ncol/EcoRV FSH-R1 cDNA fragment encompassing a part of exon 9 (from position 704), exon 9A and a part of exon 10 (to position 1068) was subcloned in pBluescript KS (Stratagene) and used to generate $\alpha-\left[{ }^{32} \mathrm{P}\right]$ UTP (Amersham)-labeled anti-sense transcripts in vitro. For FSH-R2, a 291-base pair HindIII/PvuII FSH-R2 cDNA fragment was used. This fragment encompasses a part of exon 2 (from position 168), exon 3, 
exon 4 without the first three base pairs, exon $4 \mathrm{~A}$ and a part of exon 5 (to position 406). $\alpha-\left[{ }^{32} \mathrm{P}\right]$ UTP-labeled anti-sense transcripts were generated in vitro (Sambrook et al. 1989), using T7 RNA polymerase (Stratagene). Approximately $5 \times 10^{4}$ c.p.m. FSH-R1 or FSH-R2 probe was mixed with $25 \mu \mathrm{g}$ total RNA in a total volume of $30 \mu \mathrm{l}$ hybridization mixture containing $40 \mathrm{mM}$ PIPES (pH 6.4), $1 \mathrm{mM}$ EDTA, $0.4 \mathrm{M} \mathrm{NaCl}$ and $80 \%$ (v/v) formamide. Hybridizations were performed overnight at $55{ }^{\circ} \mathrm{C}$. The RNase protection assay was performed as described (Sambrook et al. 1989).

\section{In vitro expression in COS1 cells}

COS1 cells were maintained in DMEM/HAM's F12 $(1: 1 \mathrm{v} / \mathrm{v})$ (Gibco BRL, Gaithersburg, MD, USA) containing 5\% (v/v) fetal calf serum (Sebak, Aidenbach, Germany), $2 \times 10^{5} \mathrm{IU} / 1$ penicillin (Brocades Pharma, Leiderdorp, The Netherlands) and $0 \cdot 2 \mathrm{~g} / 1$ streptomycin (Radium Farma, Milan, Italy). Cells were seeded at 10\% confluence, incubated in a humidified incubator at $37^{\circ} \mathrm{C}$ and $5 \% \mathrm{CO}_{2}$ in air, and split at $80-90 \%$ confluence.

One day before transfection, cells were seeded at 15\% confluence in $80 \mathrm{~cm}^{2}$ flasks (Nunc, Roskilde, Denmark). Calcium phosphate precipitate transfections were performed as described (Chen \& Okayama 1987). Each flask received $1 \mathrm{ml}$ precipitate containing $10 \mu \mathrm{g}$ expression plasmid $(5 \mu \mathrm{g}$ expression vector with $5 \mu \mathrm{g}$ empty vector (pSG5) for expression of the cDNAs alone, or $5 \mu \mathrm{g}$ full-length FSH receptor expression vector with either $5 \mu \mathrm{g}$ FSH-R1 or FSH-R2 expression vector for co-expression of the cDNAs), and $10 \mu \mathrm{g}$ pTZ19R (Pharmacia, Uppsala, Sweden) as carrier DNA. In order to perform hormonal stimulations, Western blotting and $\left[{ }^{125} \mathrm{I}\right] \mathrm{FSH}$-binding assays with the same batch of transfected cells, several $80 \mathrm{~cm}^{2}$ flasks were transfected with each combination of expression vectors, pooled 2 days after transfection by harvesting the cells with $0.02 \%$ EDTA in PBS without trypsin, diluted $(1: 1)$, and seeded into different tissue culture dishes. Experiments were performed 3 days after transfection.

FSH-induced cAMP production was determined in quadruplicate in 12-well plates (Costar, Cambridge, MA, USA). Cells were stimulated with different doses of recombinant human FSH (Org32489; Organon International $\mathrm{NV}$ ) in medium without serum, but containing $25 \mathrm{mM}$ HEPES pH $7 \cdot 5$ (Gibco), 0.1\% (w/v) BSA (Sigma, St Louis, MO, USA), and $0 \cdot 2 \mathrm{mM}$ isobutylmethylxanthine (Sigma). After stimulation for $2 \mathrm{~h}$, cAMP production was determined in the medium (Stoof et al. 1987). To test the effects of the truncated proteins on FSH signal transduction, conditioned media were prepared by incubation of the cells for $18 \mathrm{~h}$. Part of this medium was removed from each well, pooled and used to prepare the stimulation medium as described above.
For Western blotting, cells were cultured in $25 \mathrm{~cm}^{2}$ flasks (Nunc), and washed three times at $4{ }^{\circ} \mathrm{C}$ with HEPES-buffered saline (25 mM HEPES pH 7.5, $150 \mathrm{mM}$ $\mathrm{NaCl}, 0.9 \mathrm{mM} \mathrm{CaCl}$ ). Cells from each flask were lysed in $300 \mu \mathrm{l}$ lysis buffer $(20 \mathrm{mM}$ Tris $\mathrm{pH} 7 \cdot 5,150 \mathrm{mM} \mathrm{NaCl}$, $1 \mathrm{mM}$ EDTA, $0 \cdot 5 \%$ Triton X100, $10 \%$ glycerol, $0 \cdot 1 \mathrm{mg} /$ $\mathrm{ml}$ phenylmethylsulfonylfluoride, $1 \mu \mathrm{g} / \mathrm{ml}$ leupeptin, $1 \mu \mathrm{g} / \mathrm{ml}$ aprotinin) for $10 \mathrm{~min}$ at $4{ }^{\circ} \mathrm{C}$ on a rocking platform. Lysates were stored at $-20{ }^{\circ} \mathrm{C}$ and subsequently used for Western blotting.

Human $\left[{ }^{125} \mathrm{I}\right] \mathrm{FSH}$ (DuPont/NEN, Du Pont de Nemours GmbH, Dreieich, Germany) binding was performed using partially purified membrane preparations (Ketelslegers \& Catt 1978) isolated from cells cultured in $80 \mathrm{~cm}^{2}$ flasks (Nunc).

\section{Antibodies and Western blotting}

Peptide SP297, corresponding to residues 15-32 (CQDSKVTEIPTLPRNAI) of the rat FSH receptor, was synthesized (Atherton \& Sheppard 1989) and used to raise a polyclonal antiserum directed against the $\mathrm{N}$-terminus of the FSH receptor. Three milligrams peptide was coupled to $3 \mathrm{mg} m$-maleimidobenzoyl- $N$-hydroxysuccinimide (Pierce, Rockford, IL, USA)-activated keyhole limpet hemocyanin (Calbiochem, La Jolla, CA, USA) according to the manufacturer's instructions. The coupled peptide $(100 \mu \mathrm{g})$ was mixed with an equal volume of Freund's complete adjuvant (Difco, Detroit, MI, USA) and used to immunize a castrated male New Zealand White rabbit by subcutaneous injections. Six and twelve weeks after the initial injection, the rabbit was boosted with the same amount of coupled peptide mixed with an equal volume of Freund's incomplete adjuvant (Difco). Two weeks after the second boost, the rabbit was bled and serum was prepared. The resulting polyclonal antiserum was designated 1601-5. Pre-immune antiserum (1601-0) was obtained 2 weeks before the start of the immunization procedure.

Western blotting was performed on a Mini-Protean II gel electrophoresis and electroblotting system (Biorad, Hercules, CA, USA). The lysate $(10 \mu \mathrm{l})$ was mixed with $2.5 \mu \mathrm{l} 5 \times$ sample buffer $(50 \mathrm{mM}$ Tris pH6.8, $10 \mathrm{mM}$ DTT, 10\% (v/v) glycerol, 2\% (w/v) SDS, $8 \mathrm{M}$ urea, and $0 \cdot 001 \%$ bromophenol blue), boiled for $5 \mathrm{~min}$, separated on a 15\% SDS-polyacrylamide gel and blotted onto nitrocellulose filters (Schleicher \& Schuell, Dassel, Germany), according to the manufacturer's instructions. Non-specific binding sites were blocked for $1 \mathrm{~h}$ with $5 \%(\mathrm{w} / \mathrm{v})$ non-fat dry milk in PBS- $0 \cdot 1 \%(\mathrm{v} / \mathrm{v})$ Tween-20, incubated with antiserum 1601-5 (1: 1000) in PBS-0.1\% Tween-20/1\% non-fat dry milk for $1 \mathrm{~h}$, washed four times for $15 \mathrm{~min}$ with PBS- $0 \cdot 1 \%$ Tween-20, incubated with goatantirabbit IgG conjugated to horseradish peroxidase (Sigma) $(1: 4000)$ in PBS- $0 \cdot 1 \%$ Tween-20-1\% non-fat dry milk for $1 \mathrm{~h}$, and washed again four times with 
PBS-0.1\% Tween-20. Chemiluminescence detection of proteins with Luminol (DuPont/NEN) was performed according to the manufacturer's instructions. Blots were exposed to X-ray films (Amersham) for 1 and $60 \mathrm{~min}$.

\section{Results}

\section{Cloning of two rat FSH receptor splice variants}

To isolate a complete $\mathrm{FSH}$ receptor cDNA clone, a rat Sertoli cell cDNA library was screened with partial FSH receptor cDNA probes. Two positive plaques (FSH-R1 and FSH-R2) were isolated, sequenced, and compared with the original rat FSH receptor cDNA (Sprengel et al. 1990) and the genomic organization of the rat FSH receptor gene (Heckert et al. 1992). This comparison revealed that both clones do not encode the full-length FSH receptor, but instead are splice variants of the FSH receptor gene (Fig. 1a).

The FSH-R1 cDNA is 2487 base pairs in size and contains a stretch of 121 base pairs at the junction of exons 9 and 10 (Fig. 1b). No sequence similarities could be found with intron sequences located directly downstream of exon 9 or upstream of exon 10 , suggesting that this stretch of 121 base pairs is an alternative exon (exon 9A). The presence of exon 9A introduces a premature stop in the open reading frame, which results in truncation of the receptor protein (Fig. 1b). The FSH-R1 protein contains nearly the entire extracellular domain and has a calculated molecular mass of $32 \mathrm{kDa}$.

The other cDNA, FSH-R2, is 3239 base pairs in size. The most obvious difference compared with the fulllength FSH receptor cDNA is an extension of the $3^{\prime}$ untranslated region with approximately 800 base pairs, which is caused by the use of a putative alternative polyadenylation signal (Fig. 1c). The overlapping parts between the FSH-R2 3'-untranslated region and the 3'untranslated region of the full-length FSH receptor (Sprengel et al. 1990) are not identical. This difference may be explained by strain differences or DNA sequencing errors, as the $3^{\prime}$-untranslated region of FSH-R2 is identical to the genomic sequence of the rat FSH receptor as published by Heckert et al. (1992). FSH-R2 transcripts lack the first three bases of exon 4 , which results in a change of amino acid residues isoleucine and arginine (positions 83 and 84 of the original open reading frame) into one methionine residue in FSH-R2 (Fig. 1d). Between exons 4 and 5 , an additional stretch of 56 base pairs is present that has no homology with the intron sequences flanking exons 4 and 5 (Heckert et al. 1992), indicating that the FSH-R2 transcript also contains an alternative exon (exon $4 \mathrm{~A}$ ). The open reading frame is continued throughout exon 4A, but after transition into exon 5 , a frame shift is introduced, resulting in a premature stop codon (Fig. 1d). FSH-R2 transcripts encode a truncated FSH receptor protein composed of the $\mathrm{N}$-terminal half of the extracellular domain, with a calculated molecular mass of $16 \mathrm{kDa}$.

To verify whether the predicted truncated receptor proteins can indeed be translated from the isolated transcripts, both clones and the full-length FSH receptor were transiently expressed in COS1 cells. Total cell lysates were prepared and subjected to Western blotting (Fig. 2), using polyclonal antiserum 1601-5, raised against a synthetic peptide corresponding to amino acid residues 15-32 of the rat FSH receptor. Full-length FSH receptor protein could not be detected at the expected size of $80 \mathrm{kDa}$ (Quintana et al. 1993). Instead, a high-molecular-mass band was observed that resembled the $240-\mathrm{kDa} F S H$ receptor band observed by Dattatreyamurty et al. (1992). FSH-R1 and FSH-R2 appeared as bands of $40 \mathrm{kDa}$ and as a double band at $16 \mathrm{kDa}$ respectively (Fig. 2).

FSH-R1 and FSH-R2 $m R N A$ s are expressed in testis and in ovary

Differential regulation of the expression of the FSH-R1 and FSH-R2 mRNAs, might provide indications as to possible functions of the truncated receptor proteins. Many studies have addressed the expression of both LH and FSH receptor splice variants (e.g. LaPolt et al. 1991, 1992, Sokka et al. 1992, Vihko et al. 1992, O'Shaughnessy \& Dudley 1993, O'Shaughnessy et al. 1994, Tena-Sempere et al. 1994, Veldhuizen-Tsoerkan et al. 1994, Zhang et al. 1994, Rannikki et al. 1995). In these studies, however, mRNA expression levels were determined with Northern blotting or reverse transcriptase-polymerase chain reaction (RT-PCR) assays. Besides being relatively insensitive, Northern blotting does not readily resolve alternative transcripts that have only minor differences from the full-length receptor transcripts, such as FSH-R1, and does not, therefore, seem to be an appropriate tool to investigate mRNA expression of FSH-R1 and FSH-R2. RT-PCR, in contrast, does not have these disadvantages, but is not a quantitative method. To avoid these drawbacks, an exonspecific RNase protection assay was set up. This technique is transcript-specific, very sensitive, and quantitative. Furthermore, it is possible to monitor the expression of an alternative transcript and the full-length FSH receptor transcript in a single assay.

Examples of the RNase protection assay with the FSH-R1 and FSH-R2-specific probes are shown in Fig. $3 a$. Besides the expected bands, protected by the fulllength receptor and the FSH-R1 and FSH-R2 transcripts, other bands are observed that probably represent other FSH receptor splice variants. According to their sizes, the composition of one fragment can be postulated, whereas the etiology of the two other fragments can not readily be explained. For RNase protection assays with the FSH-R1 probe, an additional protected fragment was observed with a size of approximately 270 base pairs. This fragment may 
(a) FsH-R

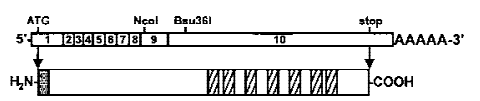

FSH-R1

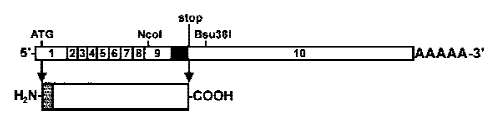

(b)

$2.4 \mathrm{~kb}$

$77 \mathrm{kDa}$

FSH-R

FSH-RI

$2.5 \mathrm{~kb}$

$32 \mathrm{kDa}$

FSH-R

FSH-R1

ZSH-R

ESH-R1$$
\text { ᄀ exerglutentis } 10
$$

$16 \mathrm{kDa}$

(d)

(C)

ESH-R GGATCCTCACCTTGAAAGACAATTATGACTCCTTCTGAAGAGCAGGCCAT

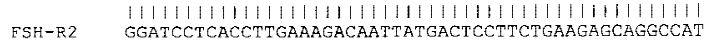

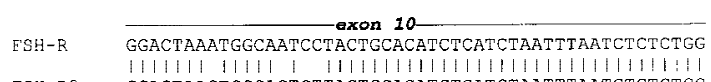

FSH-R2 GGACTAAGTGGCAGTGTTACTGCACATCTCATCTAATTTATCTCTCTGG

\begin{tabular}{l} 
exon 10 \\
\cline { 2 - 4 } ESH-R \\
\cline { 2 - 3 }
\end{tabular}

1111111111111111111111111111111111111111111
ESH-R2 GTGTGTGCATGGCAGACTGATCAGGGACATTAATGCCATGTGGCTCA

\begin{tabular}{l} 
Exon 10 \\
\cline { 2 - 4 } TCTCACACTTAAATAA.TGGTAACAGCAATAAAACAAAGCAAAACCGCA
\end{tabular}

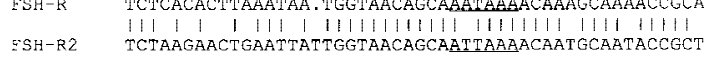

ESH-R2 ATGTGTTTGTTTTATGCTTCTGTTTGGATTATCTCAACAGATTTGGTAAA AATCATGTTCAATAGGTTAGACAGGAATTTTTCTCCAAGTTTTACAAATG AGGAAACTAAACCTCAAAGATCTCAGTGACT TCTTTGACATTGCTTGATA TATGCGGGGCAAAGCAGGATGAAGTATTCCAACTTTTCAACAATTTACAA GAGAAAT GTTATACTATTCATGCAAATATT'TACTGAAT GCCAGCAACAGT T'TGGAATGGGTCAATTTATATAGGACTACATTGCCCAGAATCCCCTTTC AGTTAGGGTGGACCATCT GAAGAGCATAGCATCAAGAAAAT CAATATTGT GCTGTGAATGGACATTGCACTGCTGAAACTTACTCAGCTCAAGGCTGCCA AGGCCATGTAGTGGGCACCCTCTACCTCTGGCTGGATCCTCCCTCTGGCC TCTGAGTGAGTGCTGGGCCACCTGTGTGGTTTTAGTACCATGATAATAAG GGACAAAGTTTCCGCAGGATGTTTTATCACCAAGGTCAGAAGCAACGAGG ACAGAACTGGGGCTCAGTTTGTCTCCCTGGGGTCGCACCCTGTGTTTGCT GAATGTATGCTTGTGATCTTTTCTTTATAAGGACATAT GCCCTGAGGACA TTGACAACATCCGTGCACATATTGCTTAGCTAGCCTTT CAARTGTAAGAG AGACAATTCCCAGTAACAAATATTTACCACCTATACATATTTGCATTCAT ACATATATATGATTCCTTCTGCTGTTCTGGTTGAACTCTAATGGAAAATA CACCTATTATATGGTATGGCAAAAAAAAAA ctctgaActTcatco H11111111111111

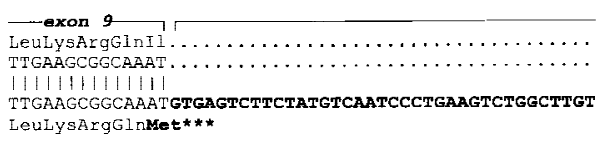

exon $9 \mathrm{~A}$

GCCGTCACACAGCATAGAATGGCTACATATTGGTGGCATGAAGAAAATCCA
LeuLysArgGlnMot***

TACATGGaGAGAGTTCCTGACTGAAGGCCTAAGCTCTGAACT TCATCCA

$2 1 4 5 \longdiv { \text { LeuProLys LeuHisGluIl eArgI legluLysAlaAsnAsnLeuLeuTyr } }$

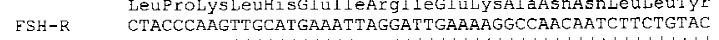
CTACCCAAGTTGCATGAAATTAGGATTGAAARGGCCAACAATCTTCTGTAC
111111111111111111111111111111111111111111111111
CTACCCAAGTG ESH-R2 CTACCCAAGTTGCATGAAAT....GATTGAAAAGGCAACAATCTTCTGTAC

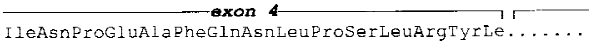

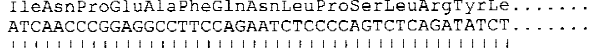

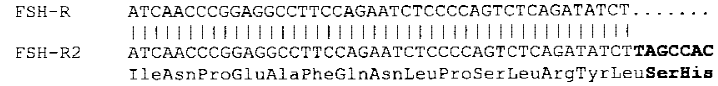

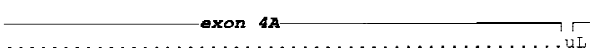

ESH-R

ESH-R2

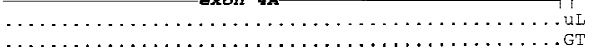

Figure 1 Characterization of FSH-R1 and FSH-R2 cDNA clones. (a) Schematic representation of the full-length FSH receptor and the FSH receptor splice variants FSH-R1 and FSH-R2. Exons are represented by open boxes, additional sequences (exon 9A, exon 4A, and the extended 3'-untranslated region of FSH-R2) by closed boxes, deletion of the first three bases of exon 4 in FSH-R2 by $\Delta$. The predicted open reading frames are shown under the RNA sequences; the putative signal peptide and transmembrane segments are indicated (stippled and hatched boxes respectively). The Ncol and Bsu36I sites, which were used to construct the full-length FSH receptor cDNA, are also indicated. (b) Sequence comparison of the full-length FSH receptor with FSH-R1. Only relevant sequences are shown: positions 840 to 869 of the full-length receptor. Encoded amino acids are shown in three-character code above or below the nucleotide sequences. Sequence identity is indicated by vertical lines, and differences from the full-length FSH receptor in bold characters. Stop codons are indicated by asterisks. (c) Sequence comparison of the full-length FSH receptor with the 3' untranslated region of FSH-R2. Only relevant sequences are shown: positions 2095 to 2294 of the full-length receptor. Consensus and putative polyadenylation signals are underlined. See Fig. $1 b$ for further explanation. (d) Sequence comparison of the full-length FSH receptor with exon 4A of FSH-R2. Only relevant sequences are shown: positions 279 to 425 of the full-length receptor. See Fig. $1 b$ for further explanation.

arise from protection by transcripts that contain additional sequences between exons $9 \mathrm{~A}$ and 10, besides the alternative exon 9A.

One of the roles of the FSH-R1 and FSH-R2 splice variants may be the modulation of $\mathrm{FSH}$ receptor function, which requires independent regulation from the fulllength FSH receptor mRNA. We therefore determined RNA expression levels in different physiological situations.
In the female, expression levels were determined in a synchronized ovarian cycle model. Thirty-day-old immature rats were stimulated with PMSG, which results in a synchronized growth of many immature follicles. Twentyfour and forty-eight hours after PMSG injection, antral follicles were present (Baarends et al. 1995). During this follicular growth phase, full-length FSH receptor expression was relatively high (Fig. 3b; ovary: 0, 24 and 48 h). 


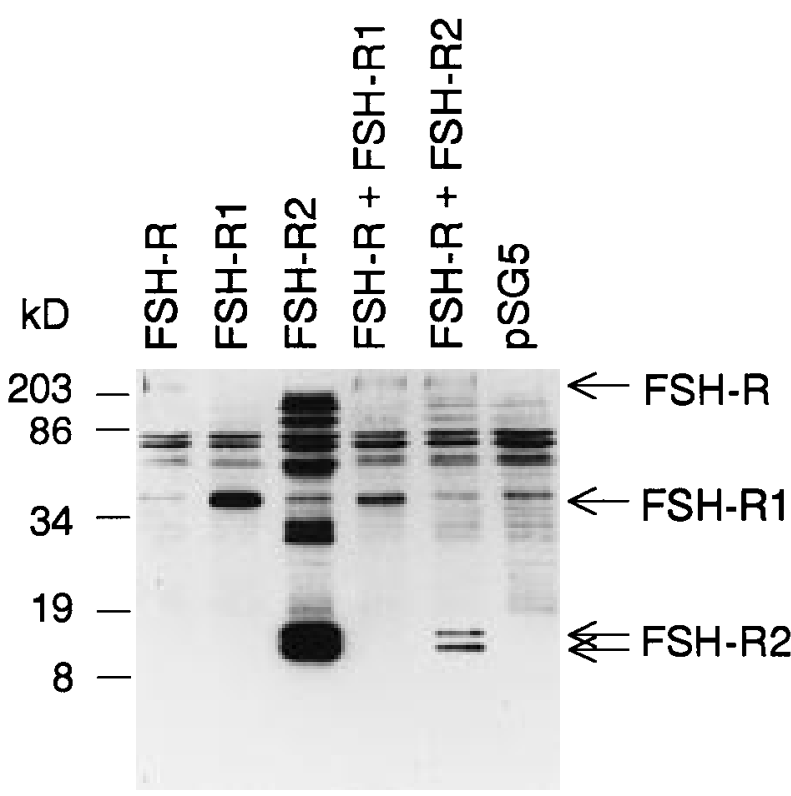

Figure 2 Western blotting of full-length FSH receptor, FSH-R1 and FSH-R2. FSH receptor expression vectors or empty vector pSG5 (control) were transiently expressed in COS1 cells. Proteins were isolated, separated on a $15 \%$ SDS-PAGE gel, and subjected to Western blotting using polyclonal antiserum 1601-5. FSH-R, FSH-R1 and FSH-R2 indicate cells that were transfected with the different receptor constructs. FSH-R+FSH-R1 and FSH-R+FSH-R2 indicate co-transfection experiments. Positions of molecular mass standards are given at the left. Arrows indicate bands that correspond to the different FSH receptor isoforms.

Fifty-six hours after PMSG injection, the antral follicles were induced to ovulate by a single injection with hCG. Ovulated follicles, that were present $72 \mathrm{~h}$ after PMSG injection, will have developed into corpora lutea at $168 \mathrm{~h}$ after PMSG injection (Baarends et al. 1995). After ovulation, full-length FSH receptor expression was downregulated and maintained at a low level (Fig. 3b; ovary: 72 and $168 \mathrm{~h}$ ). Compared with the expression of full-length FSH receptor mRNA, the FSH-R1 and FSH-R2 mRNA levels were very low, and changed in exact concordance with the changes in the expression of full-length receptor transcript.

In male rats, the splice variant mRNA expression levels were investigated during testicular development. Testes were isolated from rats at three different ages, representing different stages of testicular development: fetal rats (21days p.c.), immature rats (21-days old) and young-adult rats (56-days old). Earlier fetal stages were not included, as large amounts $(25 \mu \mathrm{g})$ of RNA could not be isolated from these testes. During testicular development, full-length FSH receptor mRNA expression was found to remain constant per total amount of RNA (Fig. $3 b$; testis). These findings are in contrast with those of Heckert \& Griswold (1991), who observed decreased FSH receptor mRNA expression in 60-day-old rats, which was probably caused by increased numbers of germ cells in the testis. Although we cannot readily explain this difference, strain differences between the animals used in these studies may have a role. As was observed in the ovary, the splice variants showed a very low level of expression, with a pattern similar to the expression pattern of full-length FSH receptor mRNA.

Full-length FSH receptor mRNA can clearly be demonstrated (Fig. 3b; SC) in cultures of Sertoli cells. In agreement with previous results (Themmen et al. 1991), stimulation of these cells for $4 \mathrm{~h}$ with $\mathrm{FSH}$ resulted in an almost complete down-regulation of FSH receptor mRNA. The low expression levels of the FSH-R1 and FSH-R2 splice variants were concomitantly downregulated by incubation of Sertoli cells with FSH.

\section{FSH-R1 and FSH-R2 do not affect full-length FSH receptor signal transduction}

The experiments described above demonstrated that both FSH-R1 and FSH-R2 are expressed in ovaries and in testes, and that their expression levels, when compared with the full-length receptor mRNA expression level, are low and not differentially regulated. A low and constant co-expression of truncated receptor proteins together with the full-length receptor molecule could play a part in modulation of FSH sensitivity of Sertoli and granulosa cells. The truncated receptors might present the ligand to the full-length receptor and increase the bioavailability of FSH, as has been described for truncated LH receptor molecules (VuHai-LuuThi et al. 1992). Alternatively, the proteins might lower FSH bioavailability by sequestering the ligand away from the full-length receptor.

The effects of FSH-R1 and FSH-R2 on the bioavailability of FSH were tested in co-expression experiments. The splice variants were transiently expressed in COS1 cells together with the full-length FSH receptor. Two days after transfection, medium was renewed and cells were incubated overnight in order to allow possible secretion of the truncated receptors into the medium. Subsequently, the cells were stimulated by adding different doses of ovine FSH to the medium and cAMP production was measured over a 2-h period. In the same experiment, using the same batch of transfected cells, the expression of the truncated proteins was verified on Western blots (Fig. 2), and full-length FSH receptor expression was determined in $\left[{ }^{125} \mathrm{I}\right] \mathrm{FSH}$-binding assays. Furthermore, the media of the transfected cells were subjected to Western blotting to determine the presence of truncated proteins (data not shown). Although these Western blots proved the presence of truncated proteins in the medium, parallel controls for the cytoplasmic/nuclear protein MAP kinase were also positive. This indicates that truncated proteins found in the medium may result from leakage from damaged cells.

It was observed that expression of the truncated receptor proteins, in the absence of full-length FSH receptor, did not result in FSH-induced cAMP production (Fig. 4 left 


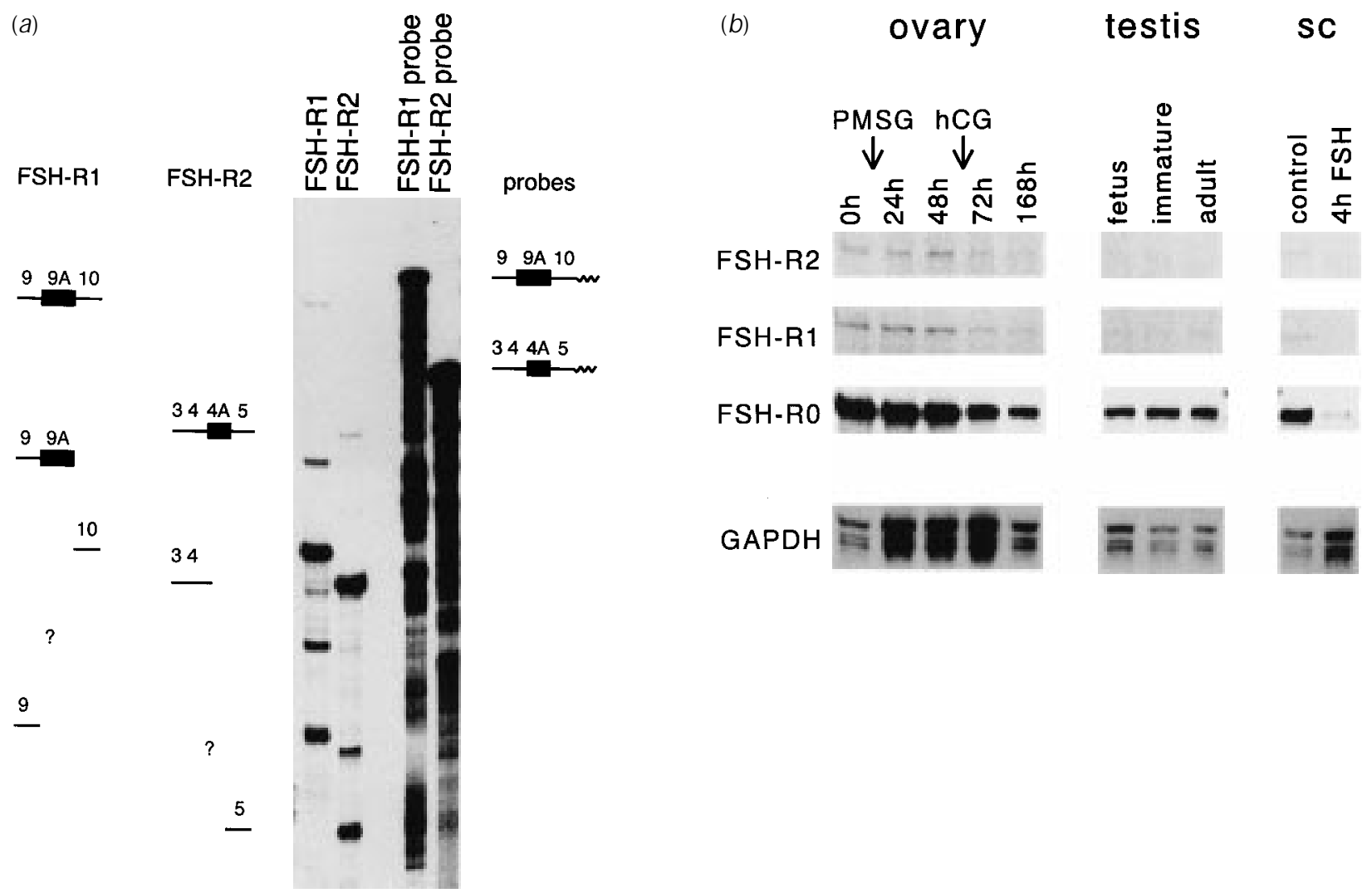

Figure 3 Full-length FSH receptor, FSH-R1 and FSH-R2 mRNA expression in ovary, testis, and Sertoli cells. (a) Examples of RNase protection assays of 21-day-old Sertoli cell RNA using FSH-R1 and FSH-R2-specific probes. On the left, the compositions of the protected fragments are indicated. The two bands that could not unequivocally be explained are indicated by question marks. The compositions of the probes are indicated at the right; vector sequences are indicated by zigzags. (b) Total RNA, isolated from ovaries of PMSG/hCGtreated immature rats (ovary), from testes of different ages (testis), or from Sertoli cells cultured for $4 \mathrm{~h}$ in the absence or presence of $500 \mathrm{ng} / \mathrm{ml} \mathrm{FSH} \mathrm{(SC)} \mathrm{were} \mathrm{subjected} \mathrm{to} \mathrm{RNase} \mathrm{protection} \mathrm{assays} \mathrm{with} \mathrm{FSH-R1} \mathrm{and} \mathrm{FSH-R2-specific} \mathrm{probes.} \mathrm{Protected} \mathrm{fragments}$ representing full-length FSH receptor, FSH-R1, or FSH-R2 mRNA expression are shown. FSH-R1 and FSH-R2 closely follow the mRNA expression pattern of the full-length FSH receptor.

panel). On the other hand, maximal stimulation of cells expressing the full-length receptor alone resulted in a sevenfold increase in cAMP production. Co-expression of either one of the truncated receptor proteins with the full-length receptor resulted in similar dose-response curves, however, basal levels of cAMP varied between cells transfected with different constructs, with the pSG5 control showing the highest basal level (Fig. 4 left panel). Over-expression of proteins in COS1 cells may negatively affect the activity of the adenylyl cyclase enzyme. Therefore, we calculated cAMP productions for each combination of constructs as net increase. Furthermore, by measuring $\left[{ }^{125} \mathrm{I}\right] \mathrm{FSH}$ binding, it was found that co-expression of FSH-R2 resulted in a minor decrease in full-length FSH receptor binding sites. Co-expression with FSH-R1 had a more pronounced effect: a $30 \%$ reduction of the number of full-length FSH receptor binding sites (data not shown). These reductions may be due to competition for translation and post-translational modification proteins, although it cannot be excluded that co-expression of the splice variants affects binding of FSH to full-length FSH receptor in the binding assay. To correct for differences in full-length FSH receptor expression, net cAMP production by cells that were transfected with full-length FSH receptor in the absence or presence of either FSH-R1 or FSH-R2 was corrected for the number of full-length FSH receptor molecules expressed, as determined in the binding assay. These calculations resulted in comparable FSH-induced cAMP production values for full-length FSH receptor alone, and for the full-length FSH receptor in combination with either one of the splice variants (Fig. 4 right panel).

\section{Discussion}

The present paper describes the cloning of alternative transcripts, FSH-R1 and FSH-R2, of the rat FSH receptor 

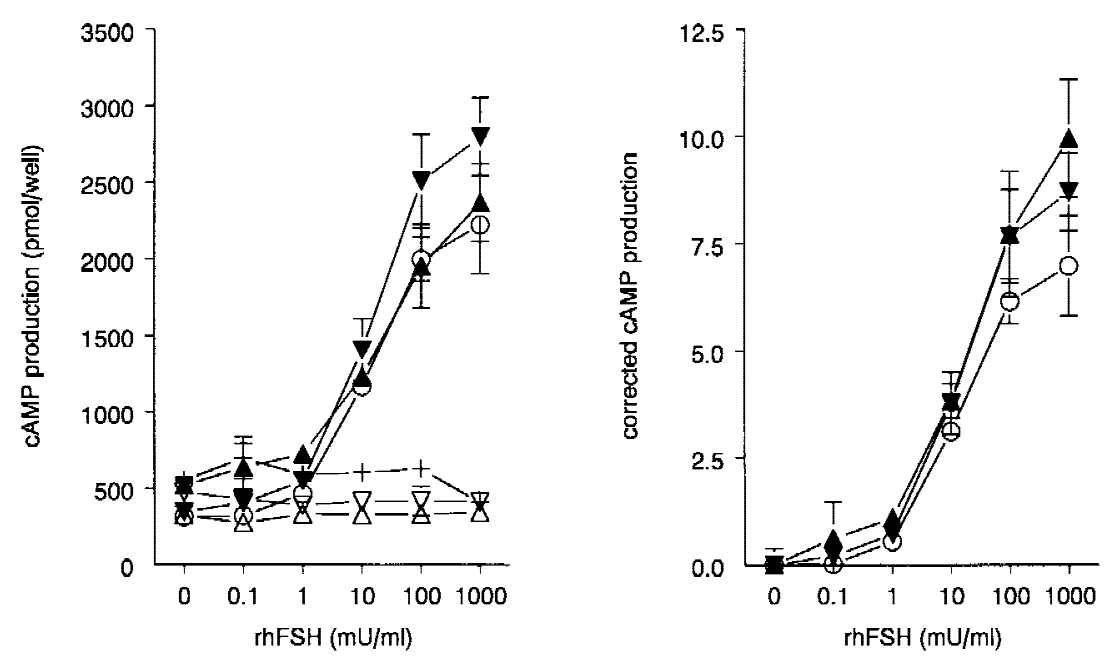

Figure 4 In vitro co-expression of full-length FSH receptor with either FSH-R1 or FSH-R2 in COS1 cells. FSH receptor expression vectors or empty vector pSG5 (control) were transfected into COS1 cells as described in Materials and Methods. Cyclic AMP production, upon stimulation with recombinant human $\mathrm{FSH}$, was measured in the medium and expressed as pmol/well (left panel) or expressed in arbitrary units after correction for basal CAMP values and the number of full-length FSH receptor binding sites (right panel). + , pSG5; $(\bigcirc)$, full-length FSH receptor alone; $(\triangle)$, FSH-R1 alone; $(\nabla), \mathrm{FSH}-\mathrm{R} 2$ alone; $(\boldsymbol{\Delta})$, full-length FSH receptor and FSH-R1; $(\boldsymbol{\nabla})$, full-length FSH receptor and FSH-R2. Co-expression of FSH-R1 or FSH-R2 did not have an effect on FSH signal transduction through the full-length receptor.

gene. Compared with the full-length FSH receptor cDNA, both transcripts contain extra sequences, which are located at an exon-exon boundary and are not homologous to flanking intron sequences (Heckert et al. 1992). This indicates that these sequences are spliced in as separate exons and do not result from the use of cryptic splice sites. FSH-R2 contains an alternative exon at the same position as the human FSH-R 5-10 transcript described by Kelton et al. (1992); however, it is unlikely that there is any evolutionary relationship between these alternative exons, as no sequence similarities could be found. The deletion of the first three nucleotides of exon 4 in FSH-R2 transcripts is probably due to the use of a cryptic splice acceptor site. The minimal sequence for a splice acceptor site is AG (Padgett et al. 1986), which is present in both the original and the alternative site. The same pyrimidine stretch $5^{\prime}$ of the splice acceptor site can be used for both sites.

On Western blots, the full-length FSH receptor appeared as a high-molecular-mass band. This is similar to bovine FSH receptor Western blots described by Dattatreyamurty et al. (1992), who identified the receptor as a $240-\mathrm{kDa}$ band. The high-molecular-mass appearance may be due to aggregation of proteins under the applied Western blotting conditions. The FSH-R1 protein, with a calculated molecular mass of $32 \mathrm{kDa}$, appeared as a band of approximately $40 \mathrm{kDa}$ on Western blots. This difference may be explained by glycosylation of the protein, as two consensus $N$-linked glycosylation sites are present in this protein (Sprengel et al. 1990), although no experiments were conducted to investigate this matter further. FSH-R2 protein, which does not contain these $N$-linked glycosylation sites, appeared as a double band of the calculated molecular mass $(16 \mathrm{kDa})$. The double band appearance of FSH-R2 is puzzling: no internal translation initiation codons, which would result in translation of a protein still containing the $\mathrm{N}$-terminal epitope, are present. An explanation might be that the double band arises from partial signal peptide cleavage, or that secondary structures may persist that were not denatured completely.

Many studies have been performed of FSH and LH receptor splice variants (reviewed by Themmen et al. 1994, Misrahi et al. 1996, O’Shaughnessy et al. 1996), but only two studies have addressed possible functional roles of truncated receptors (Sairam et al. 1996, VuHai-LuuThi et al. 1992). The study by VuHai-LuuThi et al. (1992) dealt with a truncated, transmembrane domain-lacking form of the $\mathrm{LH}$ receptor. This truncated receptor enhanced hCG-induced cAMP production, when transiently co-expressed with the full-length receptor in COS7 cells. In contrast to this, results reported here indicate that co-expression of the FSH-R1 and FSHR2 splice variants with the full-length FSH receptor does not affect FSH signal transduction. Even in the presence of large amounts of truncated receptor protein that can be 
reached in these in vitro co-expression experiments, no increase in cAMP production could be observed. Production of cAMP in the presence of maximal stimulating doses of FSH seemed to be slightly greater in cells co-expressing full-length FSH receptor and the splice variants than in cells that express full-length FSH receptor alone. However, this effect was not statistically significant and we conclude that co-expression of full-length FSH receptor with either FSH-R1 or FSH-R2 does not affect fulllength FSH receptor signal transduction. These data, together with the low and non-differentially regulated mRNA expression levels, indicate that alternative splicing of the FSH receptor pre-mRNA may not have a function.

The other study that addressed possible functional roles of truncated receptor molecules (Sairam et al. 1996) dealt with a C-terminally truncated, membrane-bound form of the ovine-FSH receptor. This receptor acts as a dominant negative regulator of FSH signal transduction in co-expression experiments. The functional role assigned to this truncated FSH receptor may be explained by its membrane location. High expression levels of truncated proteins may be reached through accumulation of the protein in the membrane. Furthermore, this truncated receptor form is located near the functional full-length receptor. FSH-R1 and FSH-R2, on the other hand, may be secreted and then diluted in the extracellular space.

Another function of alternative splicing of gonadotropin receptors may be regulation of receptor gene expression at the post-transcriptional level - that is, the prevention of the synthesis of full-length, functional FSH receptors, as has been described for $\mathrm{LH}$ receptor expression during ovarian development (Sokka et al. 1992). We could not observe differential regulation of the FSH-R1 and FSHR2 splice variants in the postnatal gonads: in ovaries during the cycle, in testes of different ages, and in cultured Sertoli cells during FSH-induced down-regulation of FSH receptor mRNA, the expression levels of both alternative transcripts showed a constant ratio to the expression level of full-length FSH receptor mRNA. If, indeed, alternative splicing of gonadotropin receptor mRNAs is a mechanism that is involved in developmental control of gonadotropin receptor expression, the splice variants FSH-R1 and FSH-R2 may result from incomplete inhibition of this mechanism at later developmental stages.

In conclusion, we report the cloning and characterization of two splice variants of the FSH receptor premRNA. Although both variants may be functional and encode truncated FSH receptor isoforms, they do not appear to have a clear role in FSH signal transduction.

\section{Acknowledgements}

Ovine FSH-S16 was provided by the NIH (Bethesda, MD, USA), and recombinant human FSH (Org32489) and Pregnyl by Organon International NV (Oss, The
Netherlands). The authors wish to thank Dr R Sprengel (University Heidelberg, Heidelberg, Germany) for providing the rat FSH receptor cDNA clones, Dr J Th J Uilenbroek and Dr P J C M van der Schoot for their discussion and support, and Dr W J A Boersma (TNOMBL, Rijswijk, The Netherlands) for synthesis of peptides and advice on antibody generation.

\section{References}

Atherton E \& Sheppard RC 1989 Solid Phase Peptide Synthesis: a Practical Approach. Oxford: IRL Press.

Auffray C \& Rougeon F 1980 Purification of mouse immunoglobulin heavy-chain messenger RNAs from total myeloma tumor RNA. European Journal of Biochemistry 107 303-314.

Baarends WM, van Helmond MJL, Post M, van der Schoot PJCM, Hoogerbrugge JW, de Winter JP, Uilenbroek JTJ, Karels B, Wilming LG, Meijers JHC, Themmen APN \& Grootegoed JA 1994 A novel member of the transmembrane serine/threonine kinase receptor family is specifically expressed in the gonads and in mesenchymal cells adjacent to the Müllerian duct. Development 120 189-197.

Baarends WM, Uilenbroek JTJ, Kramer P, Hoogerbrugge JW, van Leeuwen L, Themmen APN \& Grootegoed JA 1995 Anti-Müllerian hormone and anti-Müllerian hormone type II receptor mRNA expression in rat ovaries during postnatal development, the estrous cycle, and gonadotropin-induced follicle growth. Endocrinology 136 4951-4962.

Braun T, Schofield PR \& Sprengel R 1991 Amino-terminal leucine-rich repeats in gonadotropin receptors determine hormone selectivity. EMBO Journal 10 1885-1890.

Carr BR 1992 Disorders of the ovary and female reproductive tract. In: Williams Textbook of Endocrinology, edn 8, pp 733-798. Philadelphia: WB Saunders Company.

Chen C \& Okayama H 1987 High-efficiency transformation of mammalian cells by plasmid DNA. Molecular and Cellular Biololgy 7 2745-2752.

Dattatreyamurty B, Smith RA, Zhang SB, Santa-Coloma TA \& Reichert L Jr 1992 The size of the mature membrane receptor for follicle-stimulating hormone is larger than that predicted from its cDNA. Journal of Molecular Endocrinology 9 115-121.

Feinberg AP \& Vogelstein B 1983 A technique for radiolabeling DNA restriction endonuclease fragments to high specific activity. Analytical Biochemistry 132 6-13.

Graves PN, Tomer Y \& Davies TF 1992 Cloning and sequencing of a $1.3 \mathrm{~kb}$ variant of human thyrotropin receptor mRNA lacking the transmembrane domain. Biochemical and Biophysical Research Communications 187 1135-1143.

Graves PN, Vlase H \& Davies TF 1995 Folding of the recombinant human thyrotropin (TSH) receptor extracellular domain: identification of folded monomeric and tetrameric complexes that bind TSH receptor autoantibodies. Endocrinology 136 521-527.

Green S, Issemann I \& Sheer E 1988 A versatile in vivo and in vitro eukaryotic expression vector for protein engineering. Nucleic Acids Research 16369.

Griffin JE \& Wilson JD 1992 Disorders of the testes and male reproductive tract. In: Williams Textbook of Endocrinology, edn 8, pp 799-852. Philadelphia: WB Saunders Company.

Gross B, Misrahi M, Sar S \& Milgrom E 1991 Composite structure of the human thyrotropin receptor gene. Biochemical and Biophysical Research Communications 177 679-687.

Heckert LL \& Griswold MD 1991 Expression of follicle-stimulating hormone receptor mRNA in rat testes and Sertoli cells. Molecular Endocrinology 5 670-677. 
Heckert LL, Daley IJ \& Griswold MD 1992 Structural organization of the follicle-stimulating hormone receptor gene. Molecular Endocrinology 6 70-80.

Kelton CA, Cheng SV, Nugent NP, Schweickhardt RL, Rosenthal JL, Overton SA, Wands GD, Kuzeja JB, Luchette CA \& Chappel SC 1992 The cloning of the human follicle stimulating hormone receptor and its expression in COS-7, $\mathrm{CHO}$, and $\mathrm{Y}-1$ cells. Molecular Cellular Endocrinology 89 141-151.

Ketelslegers JM \& Catt KJ 1978 Follitropin receptors in rat testis. Characterization with enzymatically ${ }^{125}$ I-labeled human follitropin. Biochimica et Biophysica Acta 541 360-371.

LaPolt PS, Jia XC, Sincich C \& Hsueh AJ 1991 Ligand-induced down-regulation of testicular and ovarian luteinizing hormone $(\mathrm{LH})$ receptors is preceded by tissue-specific inhibition of alternatively processed LH receptor transcripts. Molecular Endocrinology $\mathbf{5}$ 397-403.

LaPolt PS, Tilly JL, Aihara T, Nishimori K \& Hsueh AJ 1992 Gonadotropin-induced up- and down-regulation of ovarian follicle-stimulating hormone (FSH) receptor gene expression in immature rats: effects of pregnant mare's serum gonadotropin, human chorionic gonadotropin, and recombinant FSH. Endocrinology $1301289-1295$.

Ligett SB, Caron MG, Lefkowitz RJ \& Hnatowich M 1991 Coupling of a mutated form of the human beta2-adrenergic receptor to $\mathrm{Gi}$ and Gs. Journal of Biological Chemistry 266 4816-4821.

Loosfelt H, Misrahi M, Atger M, Salesse R, Vu Hai-Luu Thi MT, Jolivet A, Guiochon-Mantel A, Sar S, Jallal B, Garnier J \& Milgrom E 1989 Cloning and sequencing of porcine LH-hCG receptor cDNA: variants lacking transmembrane domain. Science 245 525-528.

McFarland KC, Sprengel R, Phillips HS, Kohler M, Rosemblit N, Nikolics K, Segaloff DL \& Seeburg PH 1989 Lutropinchoriogonadotropin receptor: an unusual member of the G protein-coupled receptor family. Science 245 494-499.

Misrahi M, Beau I, Ghinea N, Vannier B, Loosfelt H, Medure G, Vu Hai MT \& Milgrom E 1996 The LH/CG and FSH receptors: different molecular forms and intracellular traffic. Molecular and Cellular Endocrinology 125 161-167.

O'Shaughnessy PJ \& Dudley K 1993 Discrete splicing alternatives in mRNA encoding the extracellular domain of the testis FSH receptor in the normal and hypogonadal (hpg) mouse. Journal of Molecular Endocrinology 10 363-366.

O’Shaughnessy PJ, Marsh P \& Dudley K 1994 Follicle-stimulating hormone receptor mRNA in the mouse ovary during post-natal development in the normal mouse and in the adult hypogonadal (hpg) mouse: structure of alternate transcripts. Molecular and Cellular Endocrinology 101 197-201.

O’Shaughnessy PJ, Dudley K \& Rajapaksha WRAKJS 1996 Expression of follicle stimulating hormone-receptor mRNA during gonadal development. Molecular and Cellular Endocrinology 125 169-175.

Padgett RA, Grabowski PJ, Monarska MM, Seiler S \& Sharp PA 1986 Splicing of messenger RNA precursors. Annual Review of Biochemistry 55 1119-1150.

Parmentier M, Libert F, Maenhaut C, Lefort A, Gerard C, Perret J, Van Sande J, Dumont JE \& Vassart G 1989 Molecular cloning of the thyrotropin receptor. Science 246 1620-1622.

Quintana J, Hipkin RW \& Ascoli M 1993 A polyclonal antibody to a synthetic peptide derived from the rat follicle-stimulating hormone receptor reveals the recombinant receptor as a 74-kilodalton protein. Endocrinology 133 2098-2104.

Rannikki AS, Zhang FP \& Huhtaniemi IT 1995 Ontogeny of follicle-stimulating hormone receptor gene expression in the rat testis and ovary. Molecular and Cellular Endocrinology 107 199-208.
Sairam MR, Jiang LG, Yarney TA \& Khan H 1996 Follitropin signal transduction: alternative splicing of the FSH receptor gene produces a dominant negative form of receptor which inhibits hormone action. Biochemical and Biophysical Research Communications 226 717-722.

Sambrook J, Fritsch EF \& Maniatis T 1989 Molecular Cloning: a Laboratory Manual. Cold Spring Harbor: Cold Spring Harbor Laboratory Press.

Sanger F, Nicklen S \& Coulson AR 1977 DNA sequencing with chain-terminating inhibitors. Proceedings of the National Academy of Sciences of the USA 74 5463-5467.

Sokka T, Hömölöinen T \& Huhtaniemi L 1992 Functional LH receptor appears in the neonatal rat ovary after changes in the alternative splicing pattern of the $\mathrm{LH}$ receptor mRNA. Endocrinology 130 1738-1740.

Sprengel R, Braun T, Nikolics K, Segaloff DL \& Seeburg PH 1990 The testicular receptor for follicle-stimulating hormone: structure and functional expression of cloned cDNA. Molecular Endocrinology 4 $525-530$.

Stoof JC, Verheijden PF \& Leysen JE 1987 Stimulation of D2receptors in rat nucleus accumbens slices inhibits dopamine and acetylcholine release but not cyclic AMP formation. Brain Research 423 364-368.

Tena-Sempere M, Zhang F-P \& Huhtaniemi I 1994 Persistent expression of a truncated form of the luteinizing hormone receptor messenger ribonucleic acid in the rat testis after selective Leydig cell destruction by ethylene dimethane sulfonate. Endocrinology 135 1018-1024.

Themmen APN, Blok LJ, Post M, Baarends WM, Hoogerbrugge JW, Parmentier M, Vassart G \& Grootegoed JA 1991 Follitropin receptor down-regulation involves a cAMP-dependent post-transcriptional decrease of receptor mRNA expression. Molecular and Cellular Endocrinology 78 R7-R13.

Themmen APN, Kraaij R \& Grootegoed JA 1994 Regulation of gonadotropin receptor gene expression. Molecular and Cellular Endocrinology 100 15-19.

Tsai-Morris C-H, Buczko E, Wang W \& Dufau ML 1990 Intronic nature of the rat luteinizing hormone receptor gene defines a soluble receptor subspecies with hormone binding activity. Journal of Biological Chemistry 265 19385-19388.

Veldhuizen-Tsoerkan MB, Ivell R \& Teerds KJ 1994 hCG-induced changes in LH/CG receptor mRNA transcript levels in the testis of adult hypophysectomized, ethane dimethyl sulphonate-treated rats. Molecular and Cellular Endocrinology 105 37-44.

Vihko KK, Nishimori K, LaPolt P \& Hsueh AJW 1992 Expression of testicular messenger ribonucleic acid for luteinizing hormone receptor in the rat: developmental regulation of multiple transcripts during postnatal life. Biology of Reproduction 46 1016-1020.

VuHai-LuuThi MT, Misrahi M, Houllier A, Jolivet A \& Milgrom E 1992 Variant forms of the pig lutropin/choriogonadotropin receptor. Biochemistry 31 8377-8383.

Xie YB, Wang H \& Segaloff DL 1990 Extracellular domain of lutropin/choriogonadotropin receptor expressed in transfected cells binds choriogonadotropin with high affinity. Journal of Biological Chemistry 265 21411-21414.

Zhang FP, Hämäläinen T, Kaipia A, Pakarinen P \& Huhtaniemi I 1994 Ontogeny of luteinizing hormone receptor gene expression in the rat testis. Endocrinology $1342206-2213$.

Received 24 November 1997

Revised manuscript received 4 March 1998

Accepted 10 March 1998 